\title{
The Fiscal Situation of Palestine: Can the Grip of Chronic Distress Be Loosened?
}

\author{
Nikolay P. Medvedev ${ }^{1}$, Dmitriy E. Slizovskiy ${ }^{1}$, Mohammed Iwaina $^{1} \& \operatorname{Olga~Nesterchuk~}^{2}$ \\ ${ }^{1}$ Peoples' Friendship University of Russia (RUDN-University), Moscow, Russia \\ ${ }^{2}$ Russian Presidential Academy of Nnational Economy and Public Administration (RANEPA), Moscow, Russia \\ Correspondence: Nikolay P. Medvedev, Peoples' Friendship University of Russia (RUDN-University), Moscow, \\ Russia. E-mail: russia@prescopus.com
}

Received: November 21, 2019

Accepted: December 23, 2019

Online Published: January 2, 2020

doi:10.5539/jpl.v13n1p19

URL: https://doi.org/10.5539/jpl.v13n1p19

\begin{abstract}
The study based on the available materials, facts and events shows chronic diseases of the Palestine's fiscal situation. The authors see the main reasons for this in the fact that Israel managed to impose on the state of Palestine not only economic, organizational and managerial, but also political mechanisms and tools for managing and regulating the financial and budgetary sector. But this is not the only reason. The analysis focuses on the international controversy between two points of view: the first shows and defends the idea of the crisis of the Palestine's fiscal situation. Its apologists attribute the reasons for this to the occupation of the Palestinian territory and to the occupation regime, undermining the possibility of creating normal living conditions for the Palestinians. The opposite view either denies the state of deep crisis in the financial and budgetary sector of Palestine or attributes it to the shortcomings and failures of the Administration unable to cope with the existing problems. The article analyzes in detail the influence of international actors, organizations and structures on the Palestine's budgetary and financial situation. The results of the study do not give a clear answer as to how the existing problems will be resolved. Theoretically, they can be positively resolved only in case of creation of a full-fledged state of Palestine. In practice, Palestine and Israel are not able to resolve the problems of the inherent antagonistic conflict by themselves. But Israel today uses the capacity and skills of its administrators, managers and financiers and with the support, first of all, of the United States maintains its leadership and receives preferences in the financial and economic sphere of the Palestinian Autonomy. In the medium term, the fiscal situation of Palestine will retain its chronic problems and contradictions. Their aggravation will be associated with the outbreaks of radicalism and armed clashes in the structure of relations between the two countries and with the rise of radicalism within them.
\end{abstract}

Keywords: Palestinian autonomy, Israel, fiscal policy of Palestine, fiscal situation of Palestine

\section{Relevance of the Research Topic}

The question of the Palestine's fiscal situation in academic terms is related to the theories of relations between politics and economics and with the position of not only researchers, but also of the centers and decision-making groups, including the Palestinian autonomy. It also depends on the theories or their combinations, what they lean toward and what they count on. In our opinion, the Xinhua News Agency in citing a number of officials and experts in the best way reflected the debate and discussion among researchers, experts and specialists. In its report, the Agency stated: "Palestinian officials warn that the financial position of the Palestinian autonomy (PA) is in danger of collapse due to a crisis in tax revenues from Israel and declining financial support from donor countries." This perspective is supported by another news agency. This position is opposed by Israeli experts and journalists. Maayan Jaffe-Hoffan, editor and head of the online content and strategy for The Jerusalem Post expressed doubt about the PA financial crisis, as the autonomy's administration refuses to take any money unless it receives all the money. For the Palestinian Authority the fiscal situation is not just a matter of choosing a theory, strategy, tactics or diverse judgments and opinions of researchers and experts. Its full attention and that of the Palestinian people remains focused on the settlement of the Palestinian-Israeli conflict and the establishment of an independent state on the Palestinian territory, adjacent to the state of Israel. Apparently, only after creating their own full-fledged state and independent government, the Palestinians can defend the very possibility of economic, financial and budgetary creativity. 
We point out to the political failure of the Palestinian Authority, its administration and administrative apparatus because it cannot be otherwise, "the years 2018 and early 2019 for Palestine were marked by an unprecedented deterioration in the humanitarian situation and record low economic indicators. Per capita income has declined, mass unemployment has increased, poverty has worsened and the environmental impact of occupation in both the Gaza strip and the West Bank has increased. The Palestinian people are deprived of the right to develop oil and gas fields, losing billions of dollars in revenue." At the same time, despite the political reproaches it is relevant to stress the great and difficult work that the Palestinian Authority is carrying out and to demonstrate it without hiding inherent failures of the Palestinian Authority's managerial, regulatory and policy administration.

We believe that the Palestinian Authority can use its political power actively and differently changing the system of economic, financial and budgetary relations. Given the specifics and features in which the Palestinian Authority operates, in our opinion, it is important to consider the financial and budgetary situation of the Autonomy by comparing the following two models:

A) recognition of the deep and chronic crisis in this sphere as a result of the economic and political relations imposed on Palestine by Israel, which infringe on Palestine; the existence of the territories occupied by Israel, the regime of their exploitation and profit-making;

B) denial of the deep crisis and shifting of the main blame to the Palestinian Authority itself, its ineffective policies in administering and managing the Palestinian economy, budget and finances.

These are parallel processes around which Palestinian and Israeli societies are mobilized, which unite radicals and those ready to agree with Israel in Palestine, "hawks" and moderates in Israel. Dozens of countries actively participate in these processes and different people from designers to the world leaders. These processes continue to develop in Palestine, conditioning the current and foreshadowing the new forms of movement along the same path

\section{Comments on the Level of Documentation and the Degree of Study of the Problem}

The scale, level and nature of the study of the declared topic includes in our opinion, three components: a) documentary support of this topic, b) scientific and analytical support, and c) information support. Briefly touching these issues, we would like to emphasize the following. First, there are documented and analytical evidence and facts showing the position regarding the Palestinian issue of the United States and the US Congress, the Soviet Union and its successor, the Russian Federation, the European Union and Arab countries.

Secondly, we can say that voluminous and well-structured, provided with quantitative data, methodologically verified knowledge about the fiscal, commercial and economic development of the Palestinian people has already been included in the scientific and analytical turnover. Since 1985, reports on the assistance to the Palestinian people have been prepared and published annually by the UNCTAD secretariat. The cumulative knowledge gained from the analysis and study of policies and practices affecting the economy of the occupied Palestinian territory reveals chronic problems that have only worsened over the years. And this is despite the fact that serious progress has been made today in identifying channels of fund diversion from the Palestinian budget to the treasury of Israel, and structures affiliated with it and with its financial and commercial organizations and institutions; an updated assessment has been prepared of the budgetary drain to Israel and other financial losses incurred by the state of Palestine as a result of restrictions imposed by the occupying power. It was possible to explain and document the causes of budget leakage and other financial losses; to estimate the share of losses as a result of budget leakage to Israel in the total amount of damage. What should be noted is that, for all the diversity of thoughts, judgments and conclusions drawn by responsible and well informed actors on financial policy and the management of financial instruments, they have one trait: an amazing ability not to show the socio-political and global nature of the severe financial consequences of the occupation and reasons that pushed the Palestinian people far back in terms of their ability to achieve the sustainable development goals. Probably, the reason is that the modern world order secures for a strong and successful country security, prosperity and sustainability at the expense of those who are less successful and less powerful at the moment.

\section{Methodology of the Problem Research}

This article is not a compromise, but a result of agreement reached on key issues between researchers from Russia and Palestine. This applies to the theoretical foundations in the structure of relations between the actions of politics on the economy, and the reverse effect, which were developed by R. Aron and K. Popper. According to this concept, the political power has a fundamental character and can control the economic power. It includes a critical but balanced assessment of the positions of Palestine and Israel in the structure of the existing relations over the past 18 years. The focus is not on the fiscal aspects and estimates, but on the political meaning of the 
fiscal measures for Palestine. The concept of Palestinian statehood with a complex of existing and potential problems raised in the Russian scientific literature is in the same methodological row.

The Russian researchers had to overcome differences caused by the fact that each researcher adheres to his/her own beliefs and views on the current world, regional and domestic processes and relations. Everyone has his/her own social experience and his/her own history of scientific formation and growth. The agreement was a consequence of the moderate expression of the views from conservative and traditional to liberal and democratic. This article is also the result of discussion and agreement between the Russian researchers and the scientific position stubbornly defended by the young Palestinian researcher.

\section{Prerequisites for a Political Analysis of the Situation around the Palestine's Fiscal Situation}

Let us try to offer preliminary data, propositions and judgments as a starting point of the issue we are investigating.

First, the Palestinian-Israeli conflict and everything connected with it has always assumed an international character. This line is clearly visible in scientific and expert assessments.

The views of history professor Steve Jones from Southwestern Adventist University may serve as a good illustration in this respect. He wrote that "the United States has traditionally supported Israel and its right to exist as a recognized state. At the same time, the US has sought to cooperate with Arab countries in the Middle East both to meet its energy needs and to provide a safe environment for Israel. These twin American goals have left the Palestinians in a diplomatic tug-of-war for nearly 65 years." The second statement by Professor Jones significantly enriches the meaning and logic of the current situation, the goals of the main subject of the international policy in the region: "The United States of America had to develop a foreign policy that both helps Israel stay safe and allows Americans an access to the Arab oil and seaports."

As to how the position on Palestine was formed in the Soviet Union, and then in the Russian Federation, it is worth recalling that the situation in the $40 \mathrm{~s}$ of the twentieth century is reflected in such documents as "Soviet-Israeli Relations: Collection of documents. Volume 1: 1941-1953, Book 1: 1941-May 1949 M., 2000"; and "Middle East conflict 1947-1956. From the documents of the foreign policy archive of the Russian Federation. Moscow, 2003." We believe it should also be said that the leadership of the Soviet Union not without guile declared its official position, the meaning of which was that the Soviet Union "did not have any direct material or other interests in Palestine. And it advocated the option of dividing Palestine into two independent democratic States - the Arab and the Jewish." The current state of international relations in the Arab world shows, and many members of the Arab public think that Russia can strengthen its role in this region. The incumbent President of Russia is looking for ways of weakening the isolation of Russia in the modern world and does not shy away from meetings with the official leadership of Israel or Palestine. At a meeting in September 2019 with Benjamin Netanyahu he discussed the situation in Syria and Iran, as well as the prospects of the Arab-Israeli "deal of the century," presented and promoted by the United States. At a meeting with Palestinian President Mahmoud Abbas in February 2018 Russian President Vladimir Putin was extremely cautious in his assessments of the existing relations of Palestine with the United States and Israel. The official website of the President of the Russian Federation does not contain anything, except assurances of continuous support of the Palestinian people by Russia, and an importance of personal assessment by Abbas of that is going on in order to compare notes and develop a joint approach to the resolution of this very complex problem (author Palestine, Israel, the United States, the Russian Federation, the UN, the EU).

It's not surprising, but we would like to draw your attention to the fact that the search engine Google in response to the search about "Palestinian-Israeli relations" gives information in a different sequence of keywords, namely "Israeli-Palestinian relations." The information and research-analytical environment is filled with data and information about the Israeli-Palestinian relations as relations of political and economic order and security between the state of Israel and the state of Palestine. No matter how neglected and unsolvable the Palestinian-Israeli conflict is, there are articles every now and then that suggest a possible improvement in the relations between the two actors and name factors conducive to a more positive dynamic.

Secondly, no one currently has any theory on how to improve the economic, financial and budgetary situation in Palestine. Every time since 2014, Palestinian and other experts have conducted studies to analyze the financial losses of Palestine due to the existing trade and economic relations with the occupying country. "Since 1967, the West Bank, including East Jerusalem and the Gaza Strip have been under Israeli military occupation, and the Palestinian people are suffering from policies that have a negative impact on the Palestinian economy and on all spheres of life," says the latest report of the Secretariat of the United Nations Conference on trade and development." If it is the case in 2019, then we must reject settlement of the Palestinian-Israeli conflict, UN 
Resolutions of 1967, 1973, and 2002 on creation in Palestine of an independent State of Palestine, ignore the international program of assistance to the Palestinian people, implemented from 1948 to the present time, forget the 1994 Paris Protocol on economic relations between the Government of Israel and the Palestine Liberation Organization, which gave rise to expectations of economic improvement of Palestine. And we must not to take into account in due measure the results of the wars between Israel and the Arab countries of 1967 and 1973, and of the first intifada of 1987 and of the second of 2000-2008, after which the balance of power significantly changed in favor of Israel. And if this cumulative experience is taken into account, it is embodied in two main forms: either in the politics and horrors of the growth of Arab radicalism and terrorism, or in the radical and military response of Israel. Another possibility are actions and preparation of a more peaceful and soft resolution of the conflict and socio-economic issues. Reality turns out to be a more complex substance to resolve a complex tangle of contradictions by these two means.

Thirdly, the question of the financial and budgetary state of Palestine and its impact on the development of the quality of life of the Palestinian people and Palestinian statehood has many dimensions of political, economic, historical and international character. The list of reasons to describe and explain the essence and meanings in this sphere of relations, and in this process, can be expanded to conceivable limits. From the standpoint of economic abstraction, it can perhaps be argued that the fiscal implications of the occupation of Palestine can be corrected by purely administrative and managerial, supervisory and policy-making, monitoring and economic measures, proven international practice tools of regulating financial and budget revenues, income and expenses. But financial and budgetary processes and mechanisms take place not in the air, but in a specific historical and political environment. The fiscal policy of Palestine is not an abstraction: it is not only a fiscal substance, but also a living systemic policy, a policy of unequal relations between Palestinians and Israelis, influenced by external actors of international and financial policy. This is a policy that needs, first of all, high-quality and effective state power. Neither the international financial institutions nor the Palestinians themselves deny that the previous political regimes of the Palestinian Authority did not always cope with the existing problems and tasks in this area. However, both researchers and Palestinians only indirectly point to this situation, reducing everything to the factor of occupation. The authors of the 2016 Report on the economic consequences of the Israeli occupation for the Palestinian people wrote: "the study assessed the results of a comprehensive alternative policy, including elements of expanded fiscal, monetary, trade and labor policies. The results of the study showed that if the sovereign state of Palestine had received the appropriate political instruments, the annual GDP would have increased by 24 percent, and the unemployment rate would have decreased by 19 percent." From this quote it is clear that: a) the state of Palestine does not have the appropriate political instruments in the sphere of economy; b) yet the Palestinian Authority has some complex alternative policy with elements of expanded regulation of key areas.

Fourthly, despite all the previous experience and discussion on this issue on a global scale, there are examples and evidence of the logic of the new approaches to it. These are also examples of how far and without restraint do active subjects of the highest level go to impose their will and power in this issue, thinking that they predetermine the meanings of processes. Here is an illustration of such actions and attitudes.

In June 2019, the US presidential administration published the economic part of the "deal of the century": 68 billion dollars are expected to be invested in the economies of Palestine, Egypt, Jordan and Lebanon. The amount is significant, and the authorities of these countries are wondering who the sponsors are. The ideologues and authors of the deal presumably focus primarily on the economic cooperation and development in the Palestinian territories. But this statement is contradicted by other information. In 2018, Washington stopped funding the United Nations Relief and Works Agency for Palestine Refugees in the Near East (UNRWA). The United States is by far the largest donor, covering about one-third of UNRWA's total budget in recent years. The story behind this aid is that the Trump Administration shares the Israeli government's view that UNRWA perpetuates the refugee problem by encouraging refugees to insist on their status and right of return, and not integrate within their current host states. According to press reports, Washington also demanded that Jordan strip the Palestinians living there of refugee status and naturalize them instead. In the same year 2018, the US stopped financial support for the PA (Palestinian Authority) and Palestinian civil society. In early 2018, the PA lost another significant source of income. During the election campaign, the Israeli cabinet decided to apply the so-called harsh law. Under the slogan "No payback for murder," Israel began to reduce transfer payments that were one of the provisions of the Israeli-Palestinian Protocol on economic relations of 1994. Dr. Muriel Asseburg, senior fellow, Middle East and Africa division, SWP, in his article, summarizing the "deal of the century," concluded: "as the experience of the last twenty-five years shows, even large investments cannot ensure the economic development of the Palestinian territories until the associated obstacles are removed...." 
Washington does not intend to take on funding. Peter Bakery Mark Lander published an article in the newspaper The New York Times in which he questioned the plan itself, and the deal to use financial leverage and strategy to achieve peace between Israel and Palestine. The views of experts and specialists are given in this regard. Their view is one of deep skepticism they do not believe that President Trump's efforts will gain momentum where previous efforts have failed. And Aaron David Miller, a former Middle East negotiator under Republican and Democratic presidents, coined his skepticism in two phrases: a) "If the United States could buy peace in the Middle East through economic development, they would have done it before"; and b) "the proverbial cart stands before the horse."

Additional evidence and facts allow us to obtain a more correct assessment and an undistorted perspective of the prerequisites in the logic of the development of processes around the budgetary and financial situation of Palestine. The current Palestinian governance structure dates back to 1994. In that year, Israel agreed with the Palestine Liberation Organization (PLO) to allow the Palestinian Authority to exercise limited dominance over the Gaza Strip and certain areas of the West Bank, subject to Israel's all-encompassing military administration. This situation dates back to the 1967 Arab-Israeli war. Under the Trump Administration, US policy towards the Palestinians has changed, there is a tension between the US Administration and Palestine. In 2017, the Trump Administration recognized Jerusalem as the capital of Israel, in 2018, the US Administration significantly reduced funding to the Palestinians, closed the PLO office in Washington, D.C., moved the U.S. Embassy from Tel Aviv to Jerusalem. Russian news agencies are actively discussing Trump's proposed "deal of the century," emphasizing that its details are unknown. The political part of the deal allegedly refers to the creation of a Palestinian state in Gaza and half of the West Bank, at the same time, no rights to Jerusalem are provided to the Palestinians. We also pay attention to the fact that when journalists asked Trump a direct question, he replied evasively: "One state, two states - as they themselves will agree."

In summary, what do we have in the balance as a basis for studying policies and practices of the financial and budgetary situation of Palestine? The judgments and conclusions of experts and scientists allow us to presumably understand the real essence of the processes that are taking place in this sphere. We emphasize, presumably understand. Dealing with facts, figures and events makes it possible to see the situation of relations between the countries.

But these same groups of formation of scientific knowledge avoid to speak, or do not understand the deep essence, the nature and character of these relations. What is the degree of their impact on the uncertain situation of the financial system of Palestine? How far is the Palestinian-Israeli conflict included in the global balance of power and centers of influence, and what is the degree of dependence on this system of Palestine and Israel? It does not seem possible today to break the cycle of vices of the Palestine's fiscal situation without taking into account the specificity of this correlation of forces and means at the disposal of Palestine and Israel and the countries of influence under the dominant model of their coverage.

\section{The Controversy around the Concepts of Palestine's Fiscal Situation: Either Consent or a War}

The fiscal situation of Palestine has passed in its evolution from 1994 to the present time through at least three stages: (1) from 1994 to 2000, (2) from 2000 to 2010, and (3) from 2010 to the present. What would we draw attention to in the first phase of the development of the financial and budgetary infrastructure, referring to the report of the UNCTAD Secretariat of 19 September 1994? This is not so much the main problems facing the Palestinian economy by the end of the 1980s, as the list of political and organizational measures, the principles of interim policy for the Palestinian self-government.

It is worth mentioning here that as early as 1990 the Palestinian department for economic affairs and planning prepared a comprehensive "Program for the development of the Palestinian national economy for 1994-2000." It is noteworthy that taking into account the specific situation in Palestine, it reflected the goals of economic development and growth based on prudence, a liberal approach, in particular through the formation of a market economy functioning on the principles of civil society, the development of large investments with the consideration of social factors. In our interpretation of the problem, equally important are the Declaration of principles on interim measures for Palestinian self-government signed in 1993 and the 1994 Bilateral agreements on the Gaza strip and the Jericho area, including the Protocol on economic relations, which laid the foundations for a process of radical transformation of political conditions and the formation of an accompanying psychological atmosphere for the development of politics, security, economy and security in the PNA. The Declaration of principles approved Israel's withdrawal from the West Bank, beginning with Jericho and the Gaza Strip, with the transfer of authority (civil administration) to the Palestinian national authority, representing the Palestinian people in the occupied territory. The economic sphere has been identified as one of the cornerstones 
of Israeli-Palestinian relations, requiring mutual respect for each other's economic interests within their own plans and priorities, equality, justice and reciprocity. Following the signing of the Declaration of principles with Israel, Palestine entered into economic agreements with its traditional Arab partners through high-level economic, social, technical, scientific and institutional cooperation to facilitate the free movement of goods, capital, services and labour.

An administrative system was created for the implementation of administrative functions in the form of institutions and departments in all spheres, except for external security, diplomatic relations and Israeli settlements. In November 1993, the Palestinian-Israeli Joint Economic Committee (SEC) was established. Directly in Palestine, the Palestinian Economic Council for development and reconstruction (PAESR) was established on 31 October 1993 to accelerate and coordinate the flow of international emergency assistance and to develop, organize and monitor programs for the reconstruction and development of the Palestinian economy. By the mid-1990s, sound monetary, fiscal and banking policies had been established in the Palestinian territory that were credible to the business community, with the prospect of establishing a sound regulatory framework and institutional system of government bodies and institutions. Most of the Arab banks closed by Israel in 1967 were opened, and new credit and financial institutions, including joint ones with international partners, were established to attract investment in various sectors. In early 1994, the International Monetary Fund prepared a preliminary report with recommendations and proposals for the establishment of a Palestinian tax system, data collection system and institutional infrastructure to manage its own economy.

Thus, in the first phase, the transitional phase, an organizational, managerial, economic environment and infrastructure were created in accordance with the mutual Israeli-Palestinian agreements. It would seem that such measures and actions were supposed to improve economic activity and strengthen the regulatory system necessary for the revival of the economy. By 1997, the Palestinian economy was finally demonstrating the potential for sustainable development. But then, the Palestinian economy and fiscal system faltered: the PNA Budget for 2000 was US\$ 1.4 billion, of which about 70 per cent was allocated to current and labour costs, so the targeted development costs fell entirely on donor financial assistance, mainly in the form of loans. At the same time, the budget deficit has decreased almost completely since 1997, however, the external debt by 1999 reached over US\$ 600 million. What is the reason? Because of the dependence of development expenditures on donor financial assistance, the growth of external debt?! There is no clear and optimal way to overcome such problems. But there is no serious debate as to the real causes of the recession and the failure of the economy beyond the above mentioned reasons. There is no clear explanation that the established system of administration and management bears its share of responsibility for the failure. Or, to put it more precisely, that the administrative and management system failed to "improve" the economy, finances and budget. So? Therefore, the game with administrative and managerial construction and reorganization continued at the next round and stage of development.

In order to strengthen the governance and finance, in particular to bring them in line with the global standards, the Supreme Development Council (SRC) was established in the PNA in 2000. It led the efforts to curb the growth of current government spending, to consolidate the dispersed public revenue accounts in the Ministry of Finance, to develop policies in the field of borrowing and disclosure of information on commercial investments and operations. These were efforts to improve economic governance of the Palestinian National Authority (PNA). Better interaction and coordination was established between ministries, in particular the Ministry of Finance, the Ministry of economy and trade, the Ministry of planning and international cooperation, the Ministry of industry, etc. In 2000, Israel and Palestine signed a new agreement expanding the list of goods allowed to be imported by the PNA from neighboring Arab States according to its own policy. In addition, Israel agreed to reimburse the PNA for its sales taxes on goods imported from or through Israel. At the same time, the PNA continued to prepare and adopt new laws regulating the political, economic and social spheres. Thus, by mid-2000, about 128 draft laws had been submitted to the Council of Ministers and the Legislative Council by the Ministry of justice of the PNA. Since mid-2000, under the supervision of the UN special coordinator for the occupied territory (UNSCO) and with the participation of ministries and special agencies of the PNA, the preparation of the "Palestinian trade policy and sectoral development strategy" has begun. Even an incomplete list of organizational measures, management decisions and activities in the second phase of the evolution of Palestinian statehood seemed to create opportunities for improvement in the economy and for the mutual consent of Palestine and Israel. Apparently, in the inertial regime from 2000 to 2002, the "free fall" of the Palestinian economy was suspended. But the economy has moved into a phase of unstable stabilization. However, the PNA was virtually unable to finance capital expenditures

With limited capacity, the Palestinian Authority was able to reduce its budget deficit to 17.6 per cent of GDP in 
2003, compared with 32 per cent of GDP in 2002. The basis for this development of the situation in the Palestinian economy was the military and political events, in particular, the intifada of al-Aqsa, which began on 29 September 2000. And the subsequent increase in terror against the Israelis, all this had a negative impact on the economic and financial condition of the PNA. In addition, its administration was declared by Israel to be an organization supporting terrorism. In view of the ongoing violence and tragic events and in an effort to create conditions for the security of civilians involved in the Palestinian-Israeli conflict, the international community has declared the need for a viable, independent and democratic Palestinian state.

By keeping Israelis and Palestinians from the harshest and most devastating consequences of war, the international community is unable or unwilling to remove the two peoples from the catastrophe. If there is one thing it can do, it is to give hope to a calmer development. That, too, was enough to create a Palestinian Shippers' Council in October 2008 to facilitate Palestinian trade. In this context, the Palestinian authority has also taken a number of measures aimed at strengthening the budget by increasing net public revenues through improved tax collection (by 6 per cent) and imposing strict rules on utility bills (which have placed an additional burden on the poor), as well as reducing public spending by freezing wages and reducing employment in the public sector. On the background of mass poverty and unemployment, the shortfall in customs revenue and encouraged smuggling of Israeli products, the real payroll decreased by $11 \%$, while the share of the current budget deficit decreased by 7.6\%. Poor export performance and rising imports contributed to a trade deficit of $79 \%$ of GDP. All this, coupled with the rapid growth of inflation and the appreciation of the new Israeli shekel, has become an obstacle to the development of the financial system of the PA. And the continued vulnerability of the budget sector was due to its heavy dependence on foreign aid, low levels of investment, and the need to rebuild the Gaza strip, which required at least US\$2 billion in resources and uncertain economic prospects in general.

After 2010, Palestinian fiscal policy entered a new phase. At the end of October 2011, the PNA was granted full UNESCO membership status, which caused the US to refuse to provide donor support, which amounted to at least US\$ 70 million per year. In 2012, despite a 1.4\% increase in budget revenues (just over US\$ 2 billion), due to a 10 per cent increase in imports, the PNA faced the most critical fiscal situation since 2006, due to the mismatch of budget revenues to projected revenues, due to increased budget spending and a reduction in donor assistance (22 per cent less than planned). In 2015, the PNA managed to reduce the overall budget deficit to $11 \%$ of GDP against the background of growth in total revenues by $9 \%$ to $22 \%$ of GDP. However, a $30 \%$ drop in donor aid almost negated the potentially positive effects of income growth. According to the expert R. Khalidi, the decrease in donor assistance, the growth of lending to the private sector ( $29 \%$ of GDP) and the debt of the Palestinian Authority to Palestinian banks (over $110 \%$ of the total banks' equity), public servants and private suppliers accounted for almost half of the banking sector and indicated the acceleration of the undesirable process of "financialization" of the Palestinian economy. Therefore, according to some specialists and experts, without easing the occupation restrictions and increased foreign aid, the Palestinian Authority was forced to choose between using riskier borrowings from the banking system and reducing important social programs, provoking new waves of discontent among the population. This version of assessing the situation and determining the choices and behavior of the Palestinian Authority is a reflection of purely economic thinking. The political and political science angle will suggest a different scheme. It is based on the recognition of the close relationship between the economic and financial situation and the reactions of political forces, parties and movements and of course of the Palestinian society. What do they testify to?

Since the radical anti-Zionist Hamas movement won the majority of seats in the February 2006 elections to the Palestinian Legislative Council, the government it formed refused to recognize the PNA's agreements with Israel. The ensuing escalation of confrontation with Israel led in 2007 to the economic blockade of the PNA in the Gaza strip, retaken by Hamas from the Israelis, and the economic boycott of the PNA by a number of countries that had previously provided financial support to the Autonomy. At the same time, despite the agreement reached between the ruling Fatah and Hamas parties and the creation of a coalition government in February 2007, relations with Israel have failed to improve. Every now and then the atmosphere between Israel and Palestine was clouded in the most brutal way in the form of military clashes. It seemed that it was possible to count on the softening of the confrontation within the framework of the policy of "asymmetric deterrence" that had become a practice. But no. The expansion of Israeli settlements in the occupied Palestinian territory, the closure of areas and the intensification of violence have contributed to the process of physical disengagement. In the end, the results achieved by 2000 in the institutional sphere were practically nullified in subsequent years.

Researchers who do not question the general direction of the policy it seems to us reduce the internal and external contradictions of Palestine to the continuation of the occupation and the "economic peace" with Israel. They consider them somehow effective in the transition phase for the creation of a viable Palestinian state, and 
subsequently they become the main deterrents, forming the basis for the creation of only a number of unrelated Palestinian areas with limited self-government.

In our view, it is not the policy of asymmetric deterrence that dominates relations between Palestine and Israel today. Israel has secured its military superiority and position as a strategic partner of the United States. And therefore, setting a goal, does not deny itself the choice of means. This also applies to relations in the field of regulation and management of the financial and budgetary sphere of Palestine. For Palestine in such a situation, there are only two possibilities - either consent or war. For Israel, the range of choice of strategic political and economic course, the list of opportunities is bigger than two.

\section{Conclusions}

The political complex of problems related to the financial and budgetary situation in Palestine, the ways and measures to resolve them have a long history. It is also an impressive scale of international support and assistance that have fixed financial and budgetary priorities of Israel in a number of treaties. But in general, the situation is not as simple as it may seem.

Events and processes in the region since 1967 have unfolded in such a way that the West Bank, including East Jerusalem, and the Gaza Strip have come under Israeli military occupation. The lack of progress in achieving peace with Israel has led to the fact that the Palestine Liberation Organization (PLO) began to actively defend the Palestinian cause at international forums. The Palestinians gained membership in the United Nations educational organization (UNESCO) in 2011. A 2012 resolution to the UN General Assembly defined Palestine as a "non-member state." At the same time, Palestine exerts international legal pressure on Israel. In April 2015, Palestine acceded to the Rome Statute of the International criminal court (ICC), and the ICC could well investigate Israeli, Palestinian or other individuals in connection with alleged crimes committed in the West Bank and Gaza Strip. This kind of situation has attracted and is attracting the attention of international organizations, the UN and researchers. And more attention is being paid to the question of the economic losses of Palestine as a result of the occupation. The 2019 UNCTAD report takes into account the findings of previous studies and reports. Based on the results of a new quantitative analysis, it examines the issue of budget losses in Palestine.

As a result of the study, we have come to a disappointing conclusion. When certain documents even those of the United Nations indicate that the goal is to expand cooperation with the government of Palestine and that there is an intention to support "the government of Palestine and its people," or that the goal is to improve the prospects of the life of the people of Palestine through the development of Palestinian statehood, even true and sincere supporters of all assistance to Palestine cannot or do not want to understand the connection of these provisions with a whole range of ideas, with the recognition of the uniqueness of this moment for Palestine, with the desire to take into account this specificity in full. Support for the Palestinian Authority to reduce the budget deficit and implement reforms while increasing its transparency and accountability - all this assistance is not directed directly to the Palestinians, or even to their administration. Direct funding goes a very different way: "Direct financial support via PEGASE and support to UNRWA are necessary to ensure the delivery of basic services to the Palestinian people, including refugees."

There is nothing more wrong and harmful than to cover up the painful relations between Jews and Palestinians by the disease of the financial and budgetary order and regulations between the two entities. Moving in this direction, there is a chance of actualization and not abstract description and explanation of not only the whole complex of blatant, acute, obvious problems and contradictions in which the Palestinian Authority is involved and with which it is directly connected: "fiscal consequences of the occupation," "loss of sovereignty over natural resources by the Palestinian people," "inability to determine and pursue its own economic, commercial and industrial policies." But to explain their political content and their dependence on politics. Unfortunately, these and other important questions for various reasons fall out of the view of researchers, to whatever scientific school they belong (fundamentalists, communitarians, libertarians, etc.). Or they are not covered to the extent that they, because of their importance and relevance, deserve. We made an attempt to explain whether such a depressing, unfavorable trend for the Palestinian people will continue, whether there is a chance to change it, who will take advantage of this chance, and under what conditions it will be possible, but the results of our study do not give a clear answer to these questions. If there is one thing that can be said for sure, it is that Palestine and Israel by themselves are not capable of solving the problems of their inherent antagonistic conflict. In the medium term, the fiscal situation of Palestine will retain the same set of chronic problems and contradictions. Their aggravation will be associated with the outbreaks of radicalism and armed clashes in the structure of relations between the two countries and with the rise of radicalist and irreconcilable sentiments among a certain 
part of the political establishment of these countries.

\section{References}

Before the "deal of the century" Netanyahu came to Putin. Retrieved October 18, 2019, from https://ria.ru/20190912/1558584963.html

Commission Implementing Decision of 23.2.2018 on the Multi-annual Action Programmer for 2018, 2019 and 2020 in favour of Palestine from the general budget of the Union. Retrieved from https://ec.europa.eu/neighbourhood-enlargement/sites/near/files/c_2018_1271_palestine_merged_document .pdf.

Economic impact of the Israeli occupation for the Palestinian people: fiscal aspects. 2 August 2019; Economic impact of the Israeli occupation for the Palestinian people. 10 October 2918; Economic impact of the Israeli occupation for the Palestinian people. 21 June 2016.

Economic impact of the Israeli occupation for the Palestinian people: fiscal aspects. 2 August 2019.

Economic impact of the Israeli occupation for the Palestinian people. 21 July 2016. p. 14/23. Retrieved October 20, 2019, from https://undocs.org/ru/A/71/174

Erakat S. Israel's step back from peace, Washingron Post, March 28, 2009.

FMI. (2009). Macroeconomic and fiscal framework for the West Bank in Gaza third review of progress. Staff report. FMI. Washington DC.

Gostev, A. (2011). Palestine is not in the UN. But in UNESCO. Radio Liberty. Retrieved October 17, 2019, from https://www.google.com/amp/s/www.svoboda.org/24377089.html

Is the Pa Facing a Financial Crisis? At Least One Israeli Ngo Says No. Retrieved October 14, 2019, from https://www.jpost.com/Middle-East/Is-the-PA-facing-a-financial-crisis-At-least-one-Israeli-NGO-says-no-5 90355

Jones, S. (n.d.). A Brief History of U.S.-Israeli-Palestinian Relations. Retrieved October 20, 2019, from https://www.thoughtco.com/early-u-s-palestinian-relations-3310398

Khalidi, R. (2012). After the Arab Spring in Palestine: contesting the neoliberal narrative of Palestinian national liberation.

Khan, M. (2004). State Formation in Palestine: Viability and Governance During a Social Transformation. London, Routledge.

Mahmoud, E., Misyef, M., \& Mutasim, E. (2014). Palestinian Fiscal Revenue Leakage to Israel under the Paris Protocol on Economic Relations. UNITED NATIONS New York and Geneva. Retrieved from https://unctad.org/en/PublicationsLibrary/gdsapp2013d1_en.pdf

Medvedev, N. P. (2018). Ivayna M. Political problems of Palestinian statehood. Issues of politology, 3(31), 7-15.

News Analysis: Palestinian Authority faces worst financial crisis amid tension with Israel. Retrieved October 12, 2019, from http://www.xinhuanet.com/english/2019-06/21/c_138159805.htm

Official website of the Palestinian government. Retrieved October 20, 2019, from http://palestinecabinet.gov.ps/GovService/GOSPub/

Palestinian Authority and International Monetary Fund, "West Bank and Gaza Economic Policy Framework-Progress Report", 31 May 2000, p. 4.

Palestinian Authority faces most serious financial crisis in its history. Israel, Middle East, News, Palestine. Retrieved October 12, 2019, from https://www.middleeastmonitor.com/20190621-palestinian-authority-faces-most-serious-financial-crisis-in-i ts-history

Palestinian Economic Policy Research Institute - MAS, MAS Economic Monitor, № 6, April 2000.

Portland Trust. Palestinian Economic Bulletin, Issue 76. January, 2013.

Report of the UNCTAD secretariat "UNCTAD Assistance to the Palestinian people: developments in the economy of the occupied Palestinian territory, in particular in foreign trade," 19 September 1994, Geneva. pp. 17, 22. Retrieved from https://unctad.org/meetings/en/SessionalDocuments/tdb41_1_d3_ru.pdf

Report of the UNCTAD secretariat "UNCTAD Assistance to the Palestinian people: developments in the economy of the occupied Palestinian territory, in particular in foreign trade," 19 September 1994, Geneva. 
pp. 17, 22. Retrieved from https://unctad.org/meetings/en/SessionalDocuments/tdb41_1_d3_ru.pdf

Report of the UNCTAD secretariat on the assistance to the Palestinian people of August 11, 2004, Geneva. pp. $11-12$.

Report of the UNCTAD secretariat on the assistance to the Palestinian people of July 6, 2009, Geneva. pp. 9-10.

Report of the UNCTAD secretariat on the assistance to the Palestinian people: state of the economy of the occupied Palestinian territory, 28 September 2016, Geneva. pp. 6-7.

Report on UNCTAD assistance to the Palestinian people: state of the economy of the occupied Palestinian territory. June 22, 2019.

Shapland, G. (n.d.). Better Israeli-Palestinian Relations Are Possible. However intractable the conflict may seem, a number of factors favour a more positive dynamic. Retrieved October 21, 2019, from https://www.chathamhouse.org/expert/comment/better-israeli-palestinian-relations-are-possible

Talks with Palestinian President Mahmoud Abbas. Retrieved October 21, 2019, from http://www.kremlin.ru/events/president/news/56849

The "Deal of the Century" for Israel-Palestine. US Proposals Are Likely to Speed Demise of Two-State Settlement. Retrieved October 20, 2019, from https://www.swp-berlin.org/10.18449/2019C20

The Middle East Conflict 1947-1956. From the documents of the archive of foreign policy of the Russian Federation. M., 2003. p. 9.

The Middle East conflict 1947-1956. From the documents of the archive of foreign policy of the Russian Federation. M., 2003.

The Palestinians: Background and U.S. Relations. Updated November 21, 2018. Retrieved October 20, 2019, from https://fas.org/sgp/crs/mideast/RL34074.pdf

Trump and Allies Seek End to Refugee Status for Millions of Palestinians. Retrieved October 20, 2019, from https://foreignpolicy.com/2018/08/03/trump-palestinians-israel-refugees-unrwaand-allies-seek-end-to-refug ee-status-for-millions-of-palestinians-united-nations-relief-and-works-agency-unrwa-israel-palestine-peaceplan-jared-kushner-greenb/

Trump to Open Middle East Peace Drive with Economic Incentives. Retrieved October 23, 2019, from https://www.nytimes.com/2019/05/19/us/politics/trump-middle-east-peace-plan.html

UN Security Council Resolution 1397 of 2002.

UNCTAD Assistance to the Palestinian people: developments in the economy of the occupied Palestinian territory, in particular in foreign trade. 19 September 1994; Report on UNCTAD assistance to the Palestinian people: state of the economy of the occupied Palestinian territory. June 22, 2019.

US confirms end to funding for UN Palestinian refugees. Retrieved from https://www.theguardian.com/world/2018/aug/31/trump-to-cut-all-us-funding-for-uns-main-palestinian-refu gee-programme

\section{Copyrights}

Copyright for this article is retained by the author(s), with first publication rights granted to the journal.

This is an open-access article distributed under the terms and conditions of the Creative Commons Attribution license (http://creativecommons.org/licenses/by/4.0/). 